\title{
Monomorphic subtelomeric DNA in the filamentous fungus, Metarhizium anisopliae, contains a RecQ helicase-like gene
}

Received: 27 August 2004/ Accepted: 19 April 2005/Published online: 2 June 2005

(C) Springer-Verlag 2005

\begin{abstract}
In most filamentous fungi, telomere-associated sequences (TASs) are polymorphic, and the presence of restriction fragment length polymorphisms (RFLPs) may permit the number of chromosome ends to be estimated from the number of telomeric bands obtained by restriction digestion. Here, we describe strains of Metarhizium, Gliocladium and Paecilomyces species in which only one or a few telomeric bands of unequal intensity are detectable by Southern hybridization, indicating that interchromosomal TAS exchange occurs. We also studied an anomalous strain of Metarhizium anisopliae, which produces polymorphic telomeric bands larger than $8 \mathrm{~kb}$ upon digestion of genomic DNA with XhoI. In this case, the first XhoI site in from the chromosome end must lie beyond the presumed monomorphic region. Cloned telomeres from this strain comprise 18-26 TTAGGG repeats, followed at the internal end of the telomere tract by five repeats of the telomere-like sequence TAAACGCTGG. An 8.1-kb TAS clone also contains a gene for a RecQ-like helicase, designated $T A H 1$, suggesting that this TAS is analogous to the $\mathrm{Y}^{\prime}$ elements in yeast and the subtelomeric helicase ORFs of Ustilago maydis (UTASRecQ) and Magnaporthe grisea (TLH1). The TAS in the anomalous strain of $M$. anisopliae, however, appears distinct from these in that it is found at most telomeres and its predicted protein product possesses a significantly longer $\mathrm{N}$-terminal region in comparison to the $M$. grisea and $U$. maydis helicases. Hybridization analyses showed that TAHI
\end{abstract}

Communicated by E. di Mauro

P. W. Inglis $(\bowtie) \cdot$ D. J. Rigden $\cdot$ L. V. Mello

M. C. Valadares-Inglis

Embrapa Recursos Genéticos e Biotecnologia,

Parque Estação Biológica, Final Av. W/5 Norte,

Brasília-DF, CEP 70770900, C.P., 02372, Brazil

E-mail: peteringlis@onetel.com

Tel: + 55-61-4484784

Fax: + 55-61-4484673

E. J. Louis

Department of Genetics, University of Leicester, Leicester, LE7 1RH, UK homologues are present in all other anomalous $M$. anisopliae strains studied, as well as in some other polymorphic strains, where the rec $Q$-like gene also appears to be telomere-associated.

Keywords Fungi - RecQ helicase ·

Telomere associated sequence $\cdot$ Recombination

\section{Introduction}

Filamentous fungi are of interest as biocontrol agents due their ability to parasitize and cause disease in many species of insects, weeds and fungal plant pathogens. Entomopathogenic fungi, particularly species of Metarhizium, Beauveria and Paecilomyces, are used to control a variety of insects in agriculture (Prior 1992; Magalhães 1997; Langewald et al. 1999; Inglis et al. 2001a), while other fungi, such as Gliocladium species, are in use to control important diseases in a variety of crops (Wraight et al. 2001). The success of a commercial biopesticide depends on the genetic stability of the organism during inoculum production and storage (Moore et al. 1993). Furthermore, the pathogenicity of isolates of some species has been reported to decline upon repeated subculturing in vitro (Fargues and Roberts 1983). Phenotypic degeneration has also been observed to occur during sector formation in some species, such as Metarhizium anisopliae, and is frequently accompanied by changes in the ability to produce secondary metabolites and enzymes (Ryan et al. 2002). However, little is known about the mechanisms associated with genetic variation in these organisms.

We previously studied the genetic variability of a group of $M$. anisopliae var. acridum ( $=M$. flavoviride $)$ isolates by restriction fragment length polymorphism (RFLP) using a telomeric probe (Inglis et al. 1999), and found the telomere-associated region to be highly polymorphic. We have also used this technique to investigate genetic variability in our collection of entomogenous 
M. anisopliae var. ansiopliae and Paecilomyces fumosoroseus species, and in isolates of Gliocladium that show antifungal activity. These fungi are all members of the ascomycete order Hypocreales. Among these, we identified strains with unusually homogeneous telomereassociated regions that yield a highly intense band and one or two weakly hybridizing fragments on Southern blots probed with a telomeric probe upon digestion with various restriction enzymes. However, most Metarhizium strains produce 12-14 equally intense telomeric bands, indicating the presence of six or seven chromosomes in this fungus, as confirmed by electrophoretic karyotyping (Valadares-Inglis and Peberdy 1998). The phenomenon of monomorphic telomere-associated DNA was previously noted in some strains of Botrytis cinerea, but most strains of this species also possess highly polymorphic telomere-associated DNA (Levis et al. 1997).

The lack of polymorphism in these telomere-associated sequences (TASs) could be explained by either multiple endogenous recombination events between chromosome ends, which leads to homogenization in these strains, or by the activity of a transposable element that preferentially inserts at a telomeric or subtelomeric target site. Thus, a degenerate LTR transposon, designated Pogo, has been identified at the VR telomere of Neurospora crassa (Schectman 1990). However, other putative copies of this element, identified by hybridization, were found only at several other non-telomeric sites. In Drosophila melanogaster, telomeres are naturally maintained by transposition and tandem duplication of specialized non-long terminal repeat (non-LTR) retrotransposons, including the LINE-like HeT-A which transposes to broken chromosome ends (Danilevskaya et al. 1997), and TART (telomere-associated retrotransposon) which also transposes and duplicates at natural chromosome ends (Levis et al. 1993). Other nonLTR retrotransposons, such as TRAS1 (Okazaki et al. 1995) and SART1 (Takahashi et al. 1997), contain gag- and pol-like ORFs and a $3^{\prime}$ poly(A) tract, and are inserted at specific sites in the telomeric repeats in the silkworm Bombyx mori.
In Saccharomyces cerevisiae, a mosaic of different repeats, varying from end to end and differing among strains, is present in the telomere-associated sequences, and these may or not contain ORFs. The subtelomeric DNA of about half the chromosome ends in S. cerevisiae contains the so-called $\mathrm{Y}^{\prime}$ element, in long and short forms; the function and origin of this element is uncertain (see review by Louis 1995). However, amplification of the $\mathrm{Y}^{\prime}$ element is part of a mechanism, which enables the cell to survive in the absence of telomerase activity (Lundblad and Blackburn 1993; Louis 1995; Yamada et al. 1998).

Due to the potential implications of telomere-associated DNA rearrangements for genome variability and stability in filamentous fungi, we cloned and characterized the monomorphic telomere-associated DNA of the $M$. anisopliae strain CG34. Its structure may help to explain the mechanism by which such telomere-associated DNAs are duplicated or transferred among chromosomes in such isolates.

\section{Materials and methods}

\section{Strains}

Ten strains of $P$. fumosoroseus, 14 strains of $M$. anisopliae var. anisopliae and 19 strains of Gliocladium sp. were used in our analysis of subtelomeric polymorphism. The $M$. anisopliae and P. fumosoroseus strains (see Tables 1 and 2 for details of their origins) were obtained from the collection of entomopathogenic fungi maintained by Embrapa Genetic Resources and Biotechnology (CENARGEN). The Gliocladium sp. strains, all of which were distinct soil isolates collected in Brazil, were obtained from the Embrapa Grape and Wine Culture Collection (kindly provided by Dr. R.M. Sanhueza). Isolates were maintained as conidial stocks stored in liquid nitrogen and were cultivated on potato dextrose agar (Difco) for production of conidial inoculum. M. anisopliae var. anisopliae strain CG34, used for TAS cloning, was originally isolated from

Table 1 Origin of $M$. anisopliae var. anisopliae strains

\begin{tabular}{|c|c|c|c|c|}
\hline No. & Strain & Date & Geographical origin & Host/substrate \\
\hline 1 & CG29 & 1988 & Manaus, AM, Brazil & Dois flavopicta (Homoptera: Cercopidae) \\
\hline 2 & CG32 & 1988 & Bahia, Brazil & Mahanarva posticata (Homoptera: Cercopidae) \\
\hline 3 & CG34 & 1988 & Manaus, AM, Brazil & Conotrachelus sp. (Coleoptera: Curculionidae) \\
\hline 4 & CG38 & 1992 & Porto Velho/RO, Brazil & Coleoptera: Scarabaeidae \\
\hline 5 & CG100 & 1988 & Brasilia, DF, Brasil & Coleoptera: Scarabaeidae \\
\hline 6 & CG210 & 1982 & Goiania, GO, Brazil & Ceratoma arcuata (Coleoptera: Chrysomelidae) \\
\hline 7 & CG236 & 1982 & Goiania, GO, Brazil & Coleomegilla maculata (Coleoptera: Coccinelidae) \\
\hline 8 & CG292 & 1990 & Adelaide, Australia & Aphodius tasmaniae (Coleoptera: Scarabaeidae) \\
\hline 9 & CG322 & 1990 & France & Melolontha melonontha (Coleoptera: Scarabaeidae) \\
\hline 10 & CG324 & 1985 & Quebec, Canada & Phyllophaga anxia, Coleoptera: Scarabaeidae \\
\hline 11 & CG374 & 1990 & South Pacific Islands & Coleoptera: Scarabaeidae \\
\hline 12 & CG390 & 1994 & New Zealand & Coleoptera: Scarabaeidae \\
\hline 13 & CG490 & 1987 & New Zealand & Conoderus sp. (Coleoptera: Elateridae) \\
\hline 14 & CG491 & 1983 & Londrina, PR, Brazil & Dois sp. \\
\hline
\end{tabular}


Table 2 Origin of $P$. fumosoroseus strains

\begin{tabular}{lllll}
\hline No. & Strain & Date & Geographical origin & Host/substrate \\
\hline 1 & CG35 & 1991 & Brasilia, DF, Brasil & Soil \\
2 & CG123 & 1987 & Manaus, AM, Brazil & Spaethiella sp. (Coleoptera: Chrysomelidae) \\
3 & CG170 & 1989 & Apopka, FL, USA & Pseudococcus sp. Homoptera: Pseudococcidae \\
4 & CG204 & 1990 & Mexico & Bemisia sp. (Homoptera: Aleyrodidae) \\
5 & CG323 & 1990 & Japan & Bombyx mori (Lepidoptera: Bombycidae) \\
6 & CG325 & 1985 & Philippines & Nilaparvata lugens (Homoptera: Delphacidae) \\
7 & CG397 & 1992 & Florida, USA & Bemisia tabaci (Homoptera: Aleyrodidae) \\
8 & CG404 & 1992 & Kathmandu, Nepal & Soil \\
9 & CG186 & 1991 & Pelotas, RS, Brazil & Anastrepha sp. (Diptera: Tephritidae) \\
10 & CG260 & 1991 & Pelotas, RS, Brazil &
\end{tabular}

Conotrachelus sp. (Coleoptera: Curculionidae) in Manaus (Amazonas State, Brazil) in 1988.

Telomere fingerprints

Extraction of fungal genomic DNA from liquid-grown mycelium, and analysis of telomeric RFLPs were described previously (Inglis et al. 1999). In order to map the extent of the element associated with the monomorphic telomeres in strain CG34, genomic DNA was digested with a range of restriction enzymes, and Southern blots were probed with the telomeric sequence from Fusarium oxysporum $[\text { TTAGGG] }]_{18}$ (Powell and Kistler 1990).

Bal31 digestion of genomic DNA from $M$. anisopliae strains CG34 and CG100

The terminal nature of the telomeric bands revealed using the telomeric probe [TTAGGG] $]_{18}$ in the anomalous strain CG34 and the normal strain CG100 was verified by partial digestion of genomic DNA with Bal31 nuclease, using a modification of the method of WeissSchneeweiss et al. (2004). Briefly, $1 \mu \mathrm{g}$ of genomic DNA was digested with $1 \mathrm{U}$ of Bal31 nuclease (New England Biolabs) in the buffer recommended by the manufacturer, for $0,15,30$ and $60 \mathrm{~min}$. Reactions were stopped by phenol-chloroform extraction, and the samples were digested to completion with EcoRI. A Southern blot was then probed with the telomeric sequence $[\mathrm{TTAGGG}]_{18}$.

Preparation and screening of a clone library enriched for terminal sequences from $M$. anisopliae strain CG34

End-repair of telomeres was conducted using a modification of the procedure of Bhattacharyya and Blackburn (1997). CG34 genomic DNA $(10 \mu \mathrm{g})$ was treated with 5 U of Vent DNA polymerase (New England Biolabs) in the recommended buffer containing $1 \mathrm{mM}$ dNTPs at $70^{\circ} \mathrm{C}$ for $1 \mathrm{~h}$. The now blunt-ended genomic DNA fragments were ligated, using T4 DNA ligase, to EcoRV- digested pBluescript II SK + plasmid (1 $\mu \mathrm{g}$; Stratagene) at $4^{\circ} \mathrm{C}$ overnight. The ligation mixture was then digested to completion with $\mathrm{XhoI}$, extracted with phenol-chloroform and religated with T4 DNA ligase. This ligation mixture, enriched for fragments containing repaired terminal DNA, was then used to transform competent Escherichia coli XL10-Gold cells (Stratagene). Transformed cells were plated on LB agar supplemented with ampicillin, IPTG and X-gal. Plates were then incubated at $28^{\circ} \mathrm{C}$ for $36 \mathrm{~h}$. This low incubation temperature was found to be essential for recovery of clones containing $M$. anisopliae telomeric repeats, presumably due to instability of this repetitive sequence in $E$. coli at $37^{\circ} \mathrm{C}$. Colony lifts were prepared on Genescreen plus membranes (Du Pont) according to standard procedures. The telomere-enriched $\mathrm{XhoI}$ library was then screened using the $\alpha-{ }^{32} \mathrm{P}[\mathrm{dCTP}]$-labeled $F$. oxysporum telomeric probe. Colonies that gave positive hybridization signals were analysed by restriction mapping. One clone whose restriction map was compatible with Southern hybridization data for the uncloned TAS was then selected for further study, and designated pMAT3A1. Another five chromosome end clones were also partially sequenced, using the M13 Reverse sequencing primer, which covers the terminal DNA ligated to the EcoRV half-site of the vector.

Sequence analysis of the telomeric clone pMAT3A1

Nested deletion sets for both strands of pMAT3A1 were prepared using the Exonuclease III digestion technique (Henikoff 1987). Clones were sequenced by the chaintermination method using the Thermo-Sequenase radiolabelled terminator cycle sequencing kit (Amersham) and $\alpha-{ }^{33}$ P-labelled ddNTPs. Initial analysis of the pMAT3A1 sequence revealed the presence of a large ORF. The sequence of the predicted product was then subjected to homology analysis. Related sequences were found using FASTA (Pearson and Lipman 1988) or BLAST (Altschul et al. 1997) searches of the Swissprot and GenBank databases. Multiple alignments and similarity assessments of full-length and partial sequences were carried out using ClustalX, and a neighbor-joining tree incorporating bootstrapped data was drawn with NJPLOT. 
Software packages were used with default settings where appropriate. The sequence of the insert in clone pMAT3A1 has been deposited with the EMBL/Genbank Data Libraries under the accession no. AF291909.

Southern analysis of fungal DNAs with the rec $Q$-like sequence from clone pMAT3A1

Southern blots of $M$. anisopliae, $P$. fumosoroseus and Gliocladium spp. DNAs that had previously been analysed with the telomeric repeat probe were re-probed with the EcoRV-BamHI fragment from pMAT3A1, which includes the bulk of the reqQ-like ORF from $M$. anisopliae strain CG34. Hybridization was carried out at moderate stringency $\left(60^{\circ} \mathrm{C}\right.$ in $1 \times$ Church and Gilbert buffer) and was followed by extended exposure to X-ray film to detect weakly hybridizing bands.

Northern analysis of the rec $Q$-like transcript in M. anisopliae strain CG34

M. anisopliae strain CG34 was grown in $100 \mathrm{ml}$ of potato dextrose broth (Difco) in a shake flask at $28^{\circ} \mathrm{C}$

Fig. 1 Analysis of telomeric RFLP. Genomic DNAs from nonselected monosporic strains of Gliocladium sp. (digested with PstI), $P$. fumosoroseus (digested with PstI) and $M$. anisopliae (digested with EcoRI) were probed with the telomeric sequence $[\text { TTAGGG }]_{18}$. The strains marked with arrowheads have monomorphic or near-monomorphic TASs for $72 \mathrm{~h}$. Harvested fungal mycelium was ground to a powder in liquid nitrogen, and total RNA was extracted using an RNeasy kit (Qiagen). A northern blot bearing the total RNA was then probed with the EcoRVBamHI fragment from pMAT3A1.

\section{Results}

Monomorphic telomere-associated DNA in strains of Gliocladium sp., P. fumosoroseus and M. anisopliae

Genomic DNA fingerprinting analysis of $M$. anisopliae, $P$. fumosoroseus and Gliocladium sp. using the telomeric probe $[\text { TTAGGG }]_{18}$ revealed anomalously strong bands in some strains of these fungi (Fig. 1), in contrast to the highly polymorphic patterns observed in most strains. Among 13 strains of $P$. fumosoroseus analysed, only one produced a monomorphic band when digested with HindIII, EcoRI or PstI, while in Gliocladium sp. monomorphic telomere-associated DNA was observed in $21 \%$ of the strains analysed. Several different $M$. anisopliae isolates were also found to display monomorphic or otherwise anomalous telomere fingerprints.

In M. anisopliae strains possessing polymorphic TASs, the number of telomeric bands observed varied widely, up to a maximum of 18 bands in strain CG322, which would correspond to a complement of nine chromosomes. Electrophoretic karyotype data are available for strain CG34. Like two other Brazilian M. anisopliae strains,
Gliocladium sp.

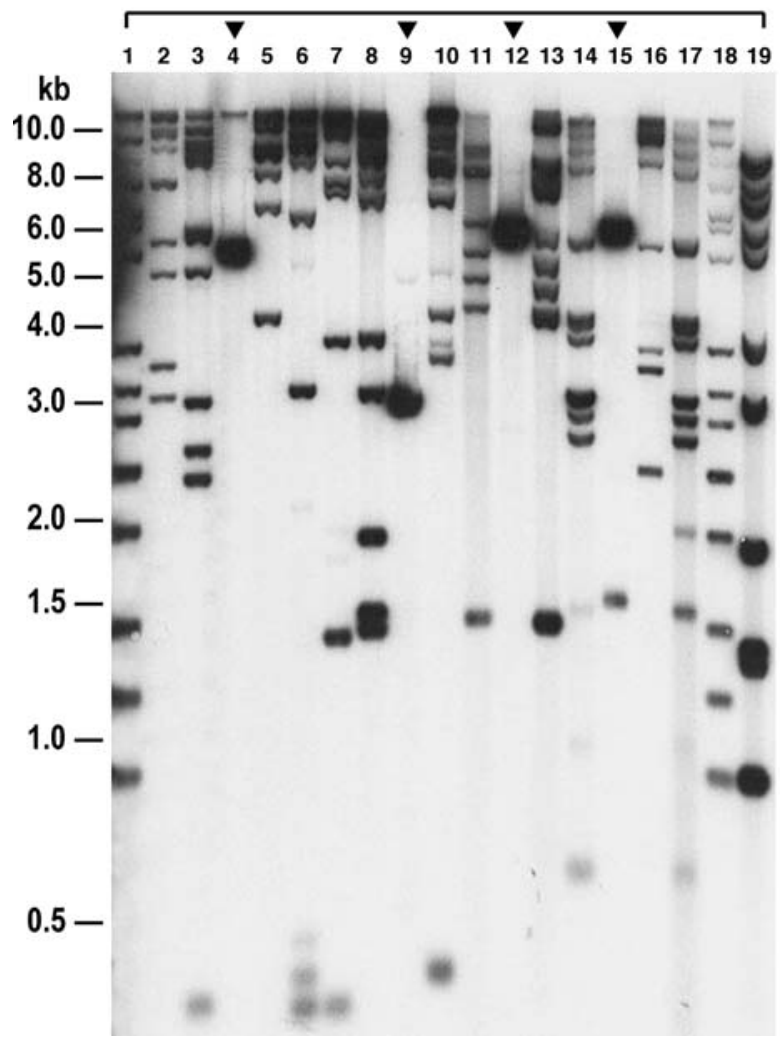

$P$. fumosoroseus

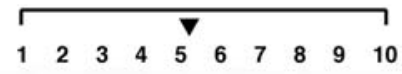

\section{M. anisopliae}

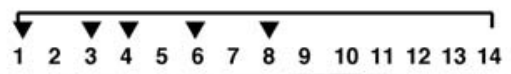

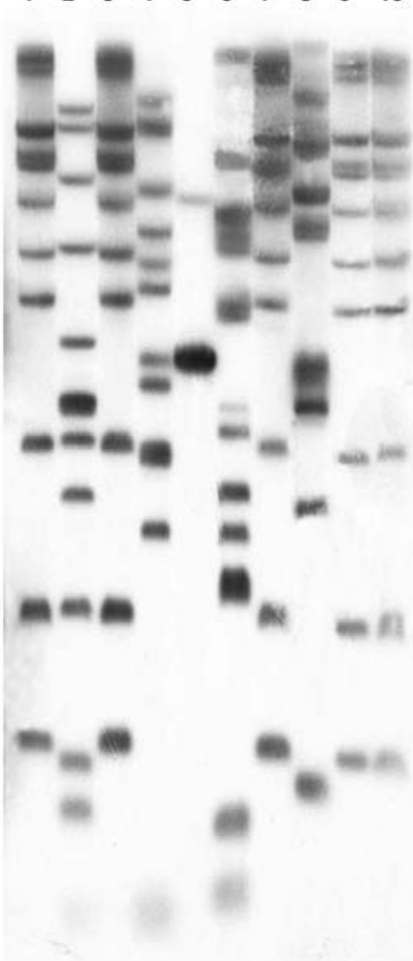

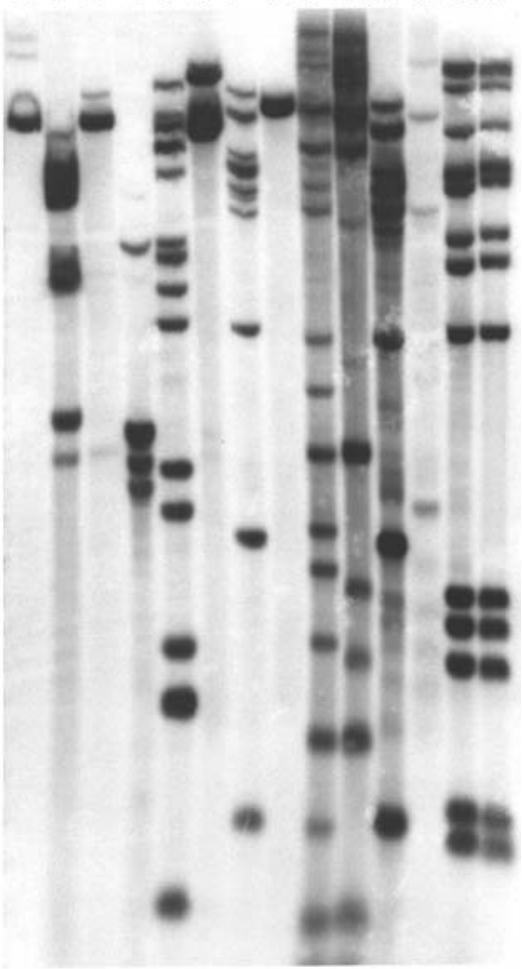


CG34 showed seven chromosomes; in a fourth isolate eight chromosomes were resolved (Valadares-Inglis and Peberdy 1998). Shimizu et al. (1992) have reported seven chromosomes in a group of $M$. anisopliae isolates from Japan. In strains with polymorphic subtelomeric DNA, the correlation between the number of bands detected with a telomeric probe and the chromosome number argues against the presence of significant tracts of telomeric repeats at non-telomeric loci in these strains. In M. anisopliae strain CG34, which gives anomalous telomeric fingerprints, and strain CG100, which yields normal telomeric fingerprints, Bal31 nuclease analysis confirmed that the bands that hybridized with the telomeric probe were exclusively terminal (Fig. 2).

The telomere-associated DNA of strain CG34 was then mapped in greater detail using different restriction enzymes (Fig. 3). The majority of enzymes produced a similar restriction pattern to EcoRI, yielding a single intense telomeric band with one or two weaker bands. However, NotI, SmaI, SpeI and XhoI produced

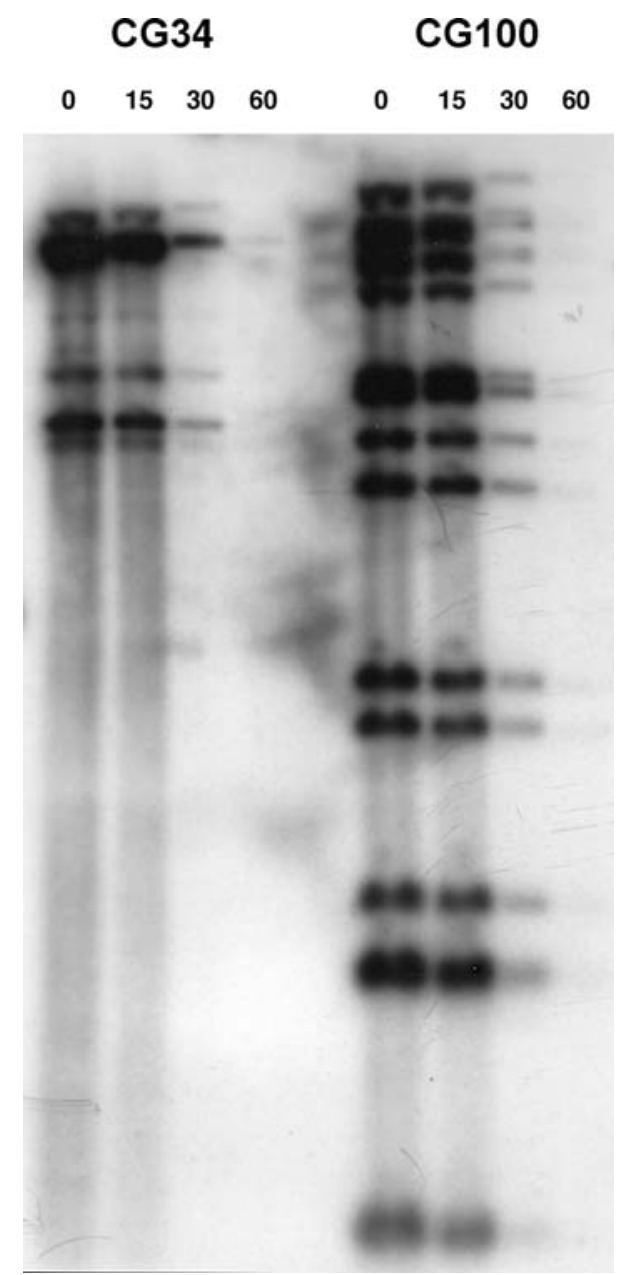

Fig. 2 Bal31 nuclease analysis of $M$. anisopliae strains CG34 and CG100. Genomic DNA (1 $\mu \mathrm{g} / \mathrm{lane})$ was digested for the times indicated (in min) above the lanes. DNA was then digested to completion with EcoRI and a Southern blot was probed with $[\text { TTAGGG }]_{18}$

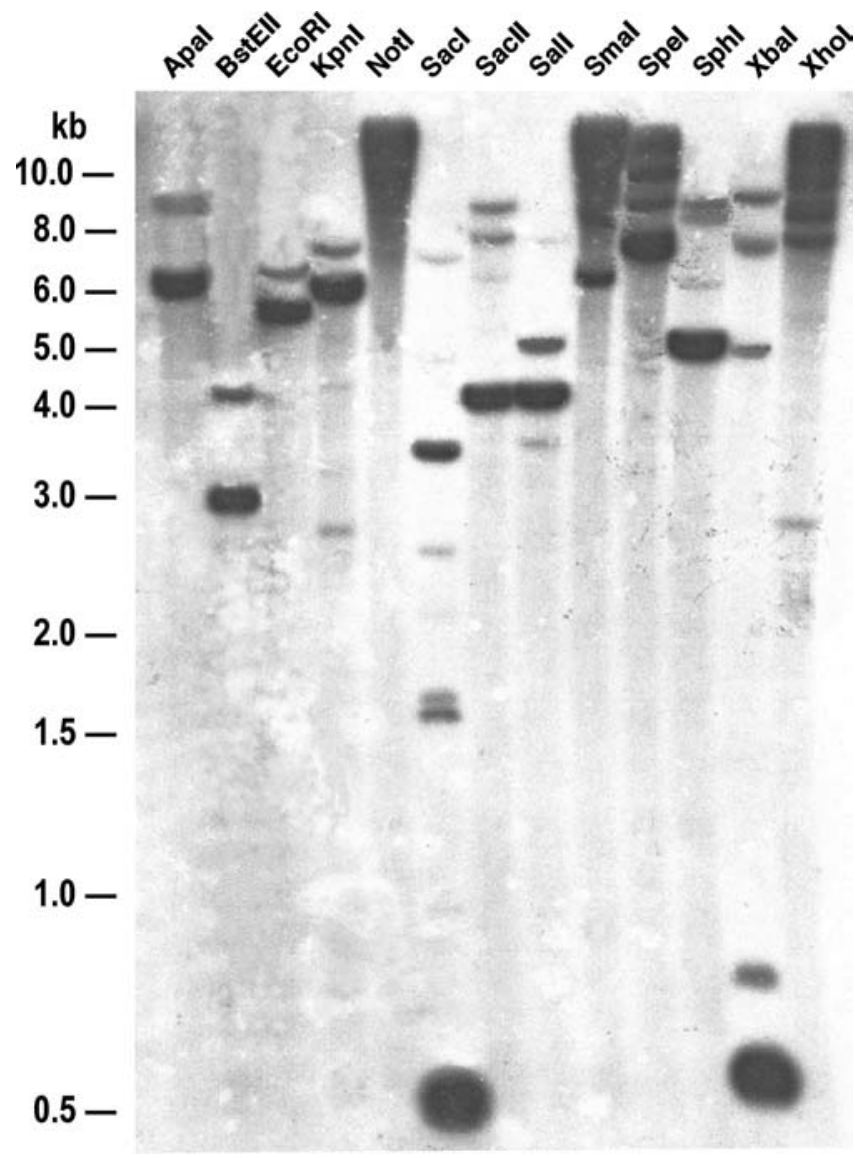

Fig. 3 Restriction mapping of monomorphic telomere-associated DNA in the $M$. anisopliae strain CG34. Various restriction enzymes were used to digest the genomic DNA and Southern blots were probed with ${ }^{32}$ P-labelled [TTAGGG] $]_{18}$

polymorphic telomeric profiles consisting of highmolecular-weight fragments, indicating that the recognition sites for these enzymes lie beyond the region presumed to be common to all chromosomes. The monomorphic bands obtained with the other enzymes ranged in size from $450 \mathrm{bp}$ ( $\mathrm{SacI}$ ) to approximately 7,000 bp (ApaI). SacI and XbaI digests also produced five and four weaker bands, respectively, of low molecular weight, in addition to the intensely hybridizing band, suggesting that certain copies of the duplicated element contain polymorphisms.

Cloning and sequence analysis of the telomere-associated sequence from $M$. anisopliae strain CG34

XhoI was chosen as the restriction enzyme for cloning purposes, since it was found to produce well-resolved, apparently fully polymorphic telomeric bands with molecular weights greater than $8.0 \mathrm{~kb}$. Following enzymatic repair of $M$. anisopliae CG34 genomic DNA ends, a terminal DNA enriched library was constructed in pBluescript II SK +, which was used to transform 
competent E. coli XL10-Gold cells (Stratagene). Six clones that hybridized to the $[\text { TTAGGG }]_{18}$ probe were identified, and these were digested with restriction enzymes in order to identify those that matched the mapping data previously obtained. One of three matching clones was selected for full sequence analysis. This clone of $M$. anisopliae telomeric and TAS DNA, designated pMAT3A1 (Fig. 4), was found to contain an insert of approximately $8.0 \mathrm{~kb}$.

The telomere repeats ligated to the EcoRV half-site of four of the terminal DNA clones, including pMAT3A1, was found to consist of variable numbers of the hexanucleotide tandem repeat TTAGGG. This is identical to the telomere repeat units found in humans and other vertebrates (Meyne et al. 1989), in the slime mould Physarum (Forney et al. 1987), in the protozoan Trypanosoma (Blackburn and Challoner 1984) and in the filamentous fungi Neurospora crassa (Schectman 1990), Ustilago maydis (Guzmán and Sánchez 1994) and Aspergillus nidulans (Bhattacharyya and Blackburn 1997). In other clones containing $M$. anisopliae telomeres, pMAT1B1 had 20 TTAGGG repeats, pMAT3A1 had 18 repeats, pMAT7C1 had 23 repeats and pMAT10A4 had 26 repeats, which equates to a telomere length of between 108 and $156 \mathrm{bp}$. Immediately adjacent to the TTAGGG repeats in all clones, including clone pMAT1B1 (which does not match the restriction map of the duplicated element) are five perfect repeats of the sequence TAAACGCTGG, which appear to form part of the telomeric array. This telomere-like sequence appears to be unique to $M$. anisopliae and is not found adjacent to the telomeres of other filamentous fungi for which sequence data are available.

No LTRs or target site duplications that would be characteristic of LTR retrotransposon insertion were identified at the centromere-proximal end of the pMAT3A1 clone (McHale et al. 1992). However, a large ORF of 4,553 bp was identified at the centromere-proximal end of pMAT3A1, $2.6 \mathrm{~kb}$ from the first [TTAGGG]

Fig. 4 Organization of the telomeric clone pMAT3A1. Map positions are derived from sequence data, but agree with the Southern hybridization data shown in Fig. 2. The full-length DNA sequence of the pMAT3A1 clone has been deposited in the GenBank/EMBL databanks under the accession no. AF291909 repeat unit (Fig. 4). BLAST (Altschul et al. 1997) searches using the amino acid sequence deduced from the large ORF as the query revealed significant similarity between the M. anisopliae telomere-associated ORF and known genes for RecQ family helicases. The best hits were two highly similar telomere-associated genes for RecQ-like helicases from the fungus $U$. maydis (Swissprot identifiers O13399 and O13400; Sánchez-Alonso and Guzmán 1998), which gave $E$ values of around $10^{-33}$ with $34 \%$ sequence identity in a 401 -residue overlap. These matches were followed by helicases giving $E$ values of $10^{-14}$ and above with typically $26 \%$ identity over stretches of about 480 residues (data not shown). These results enabled the assignment of the product of the pMAT3A1 ORF as a member of the DEAD/DExH family of helicases (for a review, see de la Cruz et al. 1999), and we named this protein TAH1 (for $M$. anisopliae telomere-associated helicase 1). No significant similarity was found between the $M$. anisopliae TAS and a class of transposable element, the helitrons, recently described in fungi including Phanarochaete chrysosporium (Poulter et al. 2003). Subsequent detailed sequence comparisons were made with RecQ-family helicases from filamentous and other fungi.

FASTA alignments (Pearson and Lipman 1988) extending over the majority of the conserved helicase core of TAH1 showed that the Metarhizium sequence agrees well with consensus helicase motifs (Fig. 5). The P-loop and DExH sequences (motifs I and II, Fig. 5) are involved in binding ATP, while motif III (TGTLP in $M$. anisopliae) forms a flexible linker between the first two domains of the helicase structure. In motif VI the two Arg residues proposed to bind ATP upon domain closure are conserved. Phylogenetic analysis was also carried out on the conserved helicase domain of the deduced $M$. anisopliae TAH1 sequence in comparison with other selected helicases (Fig. 6). The tree topology, which was generally well supported by the results of 1,000 bootstrap replicates, showed that the subtelomerically encoded helicases of the filamentous fungi $M$. anisopliae, U. maydis and M. grisea formed a diverse cluster separate from the other helicases analysed, with the $\mathrm{Y}^{\prime}$ helicase from yeast being a highly diverged outlier. The other non-subtelomeric RecQ-family helicases,

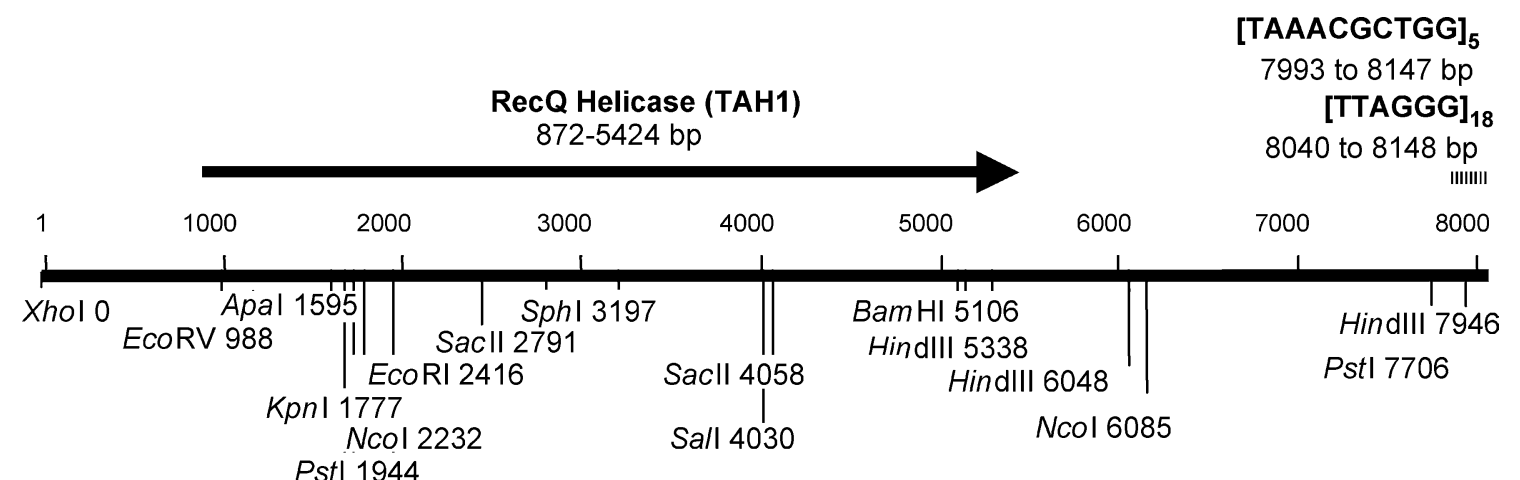

Pstl 1944

Smal 1716

Sphl 1678 
RECQ

DMBLM

BLM

MUSN

QDE 3

SGS 1

WRN

UTAS

TLH 1

TAH 1

RECQ

DMBLM

BLM

MUSN

QDE3

SGS 1

WRN

UTAS

TLH 1

TAH 1

RECQ

DMBLM

BLM

MUSN

QDE 3

SGS 1

WRN

UTAS

TL 1

ТAH 1
..MAQAEVLNLESGAKOVLQETFGYQOFRPGQEEIIDTVLS. . . . . . GNDCFVLMPTGGGKSLCYOLPAILTE. . . GVTIVISPLKSLIFDOINKLASLDICAKSL 807 SRNLKHERFOSLSFPHTKEMMKIFHKKFGLHNFRTNQLEAINAALL . . . . GEDCFILMPTGGGKSLCYQLPACVSP. . . GVTVVISPLRSLIVDQVQKLTSLDIPATYL 737 TQKSQTHGTLWGQHPWTKDVKIALKERFHLRGFRPNQLEAIDSTLS. . . . GKDTFVLMPTGGGKSLCYQLPSVISSGSTRGVTLVISPLLSLMQDQVSHLRQNKIKAYLI 774 VHAKLSMPPEKMKYAWSNDVRKALKDRFRMSGFRQNQLEAINATLG. . . . GKDAFVLMPTGGGKSLCYQLPAVVRSGKTRGITVVISPLLSLMLDQVNHLANLMIQAYAF 979 SKSNLSSKTNGPTYPWSDEVLYRLHEVFKLPGFRPNQLEAVNATLQ $\ldots$. GKDVFVLMPTGGGKSLCYQLPAVVKSGKTHGTTIVISPLISLMQDQVEHLLNKNIKASMF 752 NEGEEDDDKDFLWPAPNEEOVTCLKMYFGHSSFKPVOWKVIHSVLEE . . . RRDNVAVMATGYGKSLCFOYPPVY.VGK. . . IGLVISPLISLMEDQVLOLKMSNIPACFL 619 NSIKSVQHRERPKVTAEDLGAVARKLYCGDLQFRPGQRRAMLAIMGRRQ.AEQVVVVMPTGAGKSLLFMVGACLEGA... ETTILILPTVALRANMLAKLDVMNIRYHVW 106 DSAEEARARRFKRMRVVDIHGALQRMMGEGAEFRGCQEQVVRSIFKG. . . LTPIVQITGTGGGKSLSFILPAFCTGIT. . GTTIVVVPLVALREDLWRRCRESGIEAHVW 297 RPALESRDHHVPGEVEDRVILRALRAVLRDDSARFRSPQQKEAVIAAATGQSPVVAVLPTGGGKSLVFMVPAMLSGS ...GVTVVVAPFAKLKTQLVQRCIDAGLDCKMW 1013

Motif II

Motif III

NSTQTREQQLEVMTGCRTG.... QIRLLYIAPERLMLDN . . . . FLEHLAHWNPVLLAVDEAHCISQWGHDFRPEYAALGQLRQRFPTLPFMALTATADDTTRQDIVRLL 196 SGEQKMADVMAIYRDLESQPP.. MVKLLYVTPEKISSSARFQDTLDTLNSNNYISRFVIDEAHCVSQWGHDFRPDYKKLGVLKKRFPNVPTIALTATATPRVRLDILAQL 915 TGDKTDSEATNIYLQLSKKDP. . IIKLLYVTPEKICASNRLISTLENLYERKLLARFVIDEAHCVSQWGHDFRQDYKRMNMLRQKFPSVPVMALTATANPRVQKDILTQL 845 NGDTPSEEROWIMSTLSSHNPETHIELLYITPEMISKSHALTDRIEKLCSIOKLARVVIDEAHCVSOWGHDFRPDYKOIGAFRARIPGVPLMALTATATENVKVDVIHNL 884 NGDMNSEMRRMVFQKLDAEHPEHELQLLYVTPEMVSKNQTFVNKMMDLYRRKKLARIVIDEAHCVSQWGHDFRPDYKAIGEFRKRFPGVPVMALTATATQNVILDVKHN . 1089 SSRGTAEQRRQTFNLFING. . . . LLDLVYISPEMISASEQCKRAISRLYADGKLARIVVDEAHCVSNWGHDFRPDYKELKFFKREYPDIPMIALTATASEQVRMDIIHNL 858 G. ....SAQSENVLTDIKLG . . . KYRIVYVTPEYCSGNMGLLQQ . . LEADIGITLIAVDEAHCISEWGHDFRDSFRKLGSLKTALPMVPIVALTATASSSIREDIVRCL 718 OP.GSKKAAP $\ldots \ldots \ldots \ldots \ldots \ldots$ IVLVSTEAA. ITLAFKEYANRLLOOORLDRIVIDECHLTLTAR.SYRRSMMOLAWHVRDV.ETOTVWLTATLPPIFEDAFISHN 196 TSRGANRAAA. . . . . . . . . . IVFVTPESA.STKMFRDFVNRLRVRQELDRVVVDECHMVLDAGSEFRPQLGLLGRTIAGW.GVQVVCLTATLSPRDEEAFHQAM 389 PEARESWPRVT .............. . AAETA.SSEDFLRWAADLSVRGRLDRIVVDECHLTFTAADEYRNKLRALAQLRN.L.GCPFVFLTGTLPPLRQREFEEAM 1103

Motif IV

GLNDPLIQISSFDRPNIRYMLMEK. . . . . . F.KPLDQL . . . MRYVQEQ.RGKSGIIYCNSRAKVEDTAARLQSKG. .ISAAAYHAGLENNV.RADVQEKFQRD.D. 286 NLKNCKWFLSSFNRSNLRYRVLPK . . . . . . KGV.STLDDI . . . . SRYIRSKPQHFSGIIYCLSRKECDETSKKMCKDG. . VRAVSYHAGLTDTD.RESRQKDWLTG.K. 1008 KILRPQVFSMSFNRHNLKYYVLPK. . . . . KPK. KVAFDC . . . . LEWIRKHHPYDSGIIYCLSRRECDTMADTLQRDG . .LAALAYHAGLSDSA.RDEVQQKWINQDG. 939 RMQGCEVFTQSFNRPNLTYEVRRK .........GKHA.ELLDSI . . . . ADTIKSTYRNKCGIVYCLSRNTCEKVAEALRTNY.SIKAEHYHAGLDAET.RARTQQRWQAG.D. 979 AMEDCOTFSOSFNRPNLYYEVRMKE . . . . . . . NLIARI . . . AELIKEKYDGQTGIIYTLSRKSAENIAKNLQEKH. RIKAKHYHASITTDE. KISVOHEWOTG.R. 1182 ELKEPVFLKQSFNRTNLYYEVNKK.T. . . . . . . K. NTIFEI . . . CDAVKSRFKNQTGIIYCHSKKSCEQTSAQMQRNG . . IKCAYYHAGMEPDE.RLSVQKAWQAD.E. 950 NLRNPQITCTGFDRPNLYLEVRRK.TGN . . . . ILQDLQPF . . . . LVKTSSHWEFEGPTIIYCPSRKMTQQVTGELRKLNLSCGTYHAGMSFST.RKDIHHRFVR.D.E. 814 KLTKPLIVRESTNRSNLCYSVRTAEHRMSGMTCY.DAVRVVDE.CRARTDIWNGQRDRIIVYCTSKELVARLAEMLGCA. . . . AYSSESGSEADKAAIIQDWICGKG. 297 GFOGNMVTIYRVLTSRHNIEYRVRYTKKVGGKOO. AIEEAVEEA.VGEARLRYGDDTRMIVYRGTIKRTETIGESLGCP . . . . IYHAGVADENGKKIIMOAWMREGG. 490 LLQNPLYIRASSHRVNARYAVRRVKTGQGIMEVK. RLVEAWQQGGNDNGNKPVPVKKGVIYCLSHAKCRALARQLGCH . YYHALREDSDSQFAAQREAGFQSWVQG. E. 1208

Motif $\mathrm{V}$

Motif VI

作 MRVICATVAFGMGIDKPDVRFVLHYSLPKSIEGYYQEAGRAGRDGDVADCILYYNYSDMLRIKKMLDSDKALQYNVKKIHVDNLYRIVGYCENLTDCRRAQQLDYFGEH . 1117 CQVICATIAFGMGIDKPDVRFVIHASLPKSVEGYYQESGRAGRDGEISHCLLFYTYHDVTRLKRLIMMEKDGNHHTRETHFNNLYSMVHYCENITECRRIQLLAYFGENG 1049 VHVIVATIAFGMGIDKPDVRFVIHHSIPKSLEGYYQETGRAGRDGRRSGCYLYFSHRDVSTMQSMIEKNEDSDDVQKGRQTRMLNDVVKYCENANDCRRVQILAYFSES . 1088 VKVVVATIAFGMGIDKPDVRFVIHOHIPKSLEGYYOETGRAGRDGKPSDCYLYFAYGDIOSLRRMIADGE . GDYAOKEROLOMLNRVVSYCESOHTCRREEVLRYFGEE. 1290 IQVICATVAFGMGIDKPDVRFVYHFTVPRTLEGYYQETGRAGRDGNYSYCITYFSFRDIRTMQTMIQKDKNLDRENKEKHLNKLQQVMAYCDNVTDCRRKLVLSYFNED. 1059 IQCVIATIAFGMGINKADIRQVIHYGAPKDMESYYQEIGRAGRDGLQSSCHVLWAPADINLNRHLLTEIRNEKFR . . LYKLKMMAKMEKYLHSSR.CRRQIILSHFEDKQ 921 SPVIVATSALGVGFDYPHVRFVIHLLGPDLLTDFSQESGRAGRDGMPAESILLAGP . . QLDDRAPASGKASSAEKGKVAPGADKEAMQLYRSRKYCLRGVLSQLLDQR. 403 . VIAATNALGVGLDVPDVRAVIHAGAPRRLRDYAQESGRAGRDGOKSEAIIVLR $\ldots \ldots \ldots \ldots \ldots \ldots \ldots$ AGEGGVGNTGLEVEMVEYICGDACRRSVLNEVMDGQ

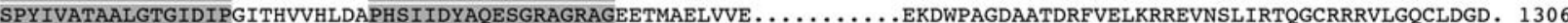

Fig. 5 Multiple alignment (ClustalX) of the core domains of selected helicases of the RecQ family. The shaded areas indicate the conserved helicase motifs proposed by Gorbalenya et al. (1989). The genes aligned were: RECQ: $E$. coli rec $Q$ helicase gene; DMBLM: Drosophila melanogaster rec $Q$ helicase homolog; BLM: Homo sapiens Bloom Syndrome gene; MUSN: Aspergillus nidulans RecQ helicase; QDE3: Neurospora crassa QDE3 gene (similar to RecQ helicase); SGS1: Saccharomyces cerevisiae DNA helicase gene; WRN: H. sapiens Werner Syndrome gene; UTAS: Ustilago maydis clone UT5 telomere-associated recQ-like helicase (UTASrecQ) gene; TLH1: Magnaporthe grisea telomere-linked helicase 1 gene; TAH1: Metarhizium anisopliae telomere-associated helicase gene (this study)

including the yeast SGS1 and human WRN and BLM helicases, formed a distinct clade of higher overall similarity than that encompassing the subtelomeric helicases. Cluster analysis of the complete amino acid sequences of these helicases produced a tree topology closely resembling that recovered on the basis of the helicase domains alone (data not shown). This is likely to be related to the degree of divergence of these sequences outside of the conserved helicase core. Furthermore, the relative position of the helicase domain in the proteins was also variable, being biased either towards the central region of the proteins in M. anisopliae, or towards the $\mathrm{N}$-terminal end of the proteins in the RecQ helicases from U. maydis and M. grisea (Fig. 7).
Southern and northern hybridization analysis of the TAH1 sequence from M. anisopliae strain CG34

Significant cross-hybridization was detected between the $E c o \mathrm{RV}-$ Bam HI fragment from pMAT3A1, which represents the bulk of the TAHI gene from $M$. anisopliae strain CG34, and the DNA of several other M. anisopliae strains digested with EcoRI. Strains that crosshybridized significantly with the probe included all those possessing anomalous telomere fingerprints, namely, CG29, CG38, CG210 and CG292 (Fig. 8). In strains possessing normal, polymorphic TASs, cross-hybridization with the probe was either extremely weak or absent. Exceptions to this were the completely polymorphic strains CG490 and CG491, in which strongly hybridizing signals were obtained. In several cases, some of the cross-hybridizing bands appeared to have the same molecular weights as a particular telomeric band. This holds for strain CG210, where two (the largest) of the three bands detected exactly matched bands that hybridized with the $[\text { TTAGGG }]_{18}$ probe, and for strains CG490 and CG491, where the TAH1-hybridizing bands also appeared to be identical in size to those that hybridized to the telomeric probe. Under the conditions utilized, no significant hybridization signals were de- 
Fig. 6 Unrooted neighborjoining tree (Saitou and Nei 1987) based on helicase domain sequences of selected RecQfamily helicases from Fig. 5. Percent divergences were calculated using ClustalX and are indicated by the scale bar. The results of 1,000 bootstrap trials of the branch data are indicated on the tree nodes. The tree was drawn using NJPlot

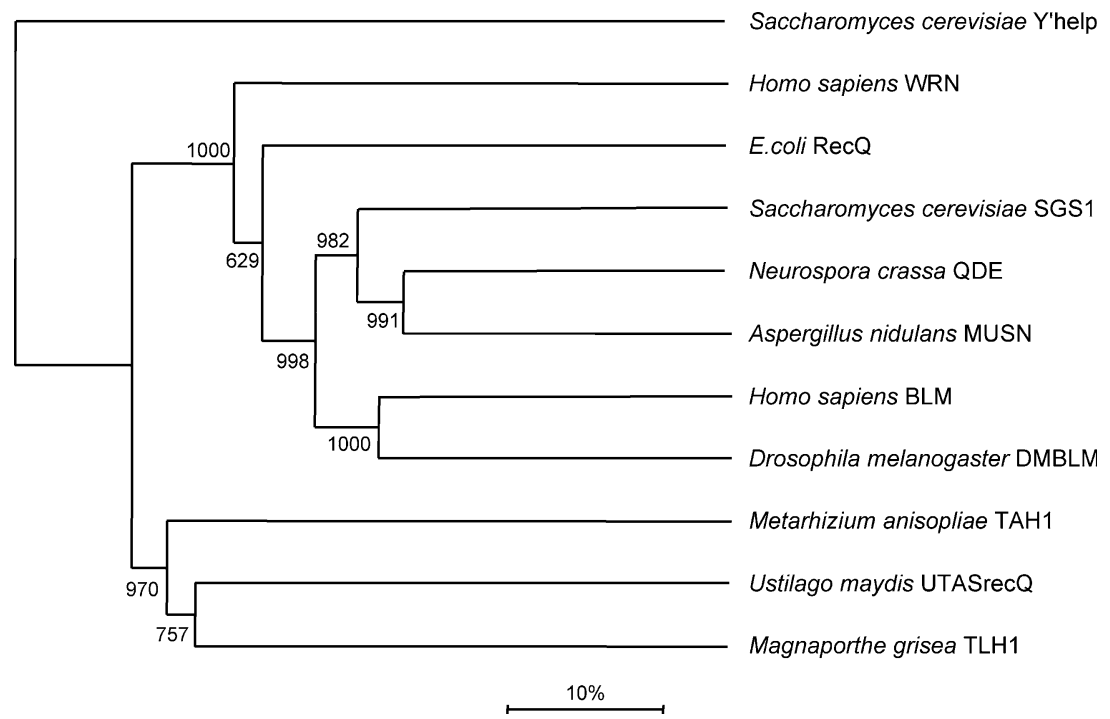

tected with the $M$. anisopliae RecQ helicase probe in genomic DNAs of $P$. fumosoroseus or Gliocladium spp. Furthermore, no $T A H 1$ transcript could be detected on northern blots bearing RNA from $M$. anisopliae strain CG34 grown under normal conditions.

\section{Discussion}

We have described here our observations on polymorphism in subtelomeric sequences in strains of the filamentous fungi Gliocladium sp., P. fumosoroseus and $M$. anisopliae. Telomeric probes have previously been used for DNA fingerprinting of filamentous fungi such as U. maydis (Sanchez-Alonso et al. 1996), Metarhizium sp. (Inglis et al. 1999), Nomuraea rileyi (Boucias et al. 2000), Cercospora caricis (Inglis et al. 2001b) and Beauveria sp. (Viaud et al. 1998). On the basis of these studies, a high level of subtelomeric polymorphism is expected. However, we observed that strains that yield anomalously low numbers of telomeric bands appear to occur relatively frequently in our collection of filamentous fungi. A TAS clone, pMAT3A1, derived from the anomalous $M$. anisopliae strain CG34 contains a gene (TAHI) for a RecQ-like helicase, and the restriction map of this clone matches the pattern expected from genomic telomeric fingerprinting in this strain. It is likely, therefore, that the anomalous pattern of telomeric fragments has arisen by the acquisition of a TAS containing this TAHl gene by most of the telomeres. Apparently interchromosomal recombination has placed this sequence in a fixed position relative to the telomere repeats (Fig. 9). Most strains that give anomalous telomeric fingerprints displayed a few weak bands in addition to one highly intense telomeric band, suggesting that the event responsible for the apparent terminal interchromosomal duplications in these strains either did not involve all chromosome ends, or that the sequence became unstable at some point. However, strains CG292 (Fig. 1, M. anisopliae, No. 8), CG323 (Fig. 1, P. fumosoroseus, No. 5), 3GDO1, 10GDO2, GSJ1 and GFO3 (Fig. 1, Gliocladium sp. Nos. 4, 9, 12 and 15) showed a
Fig. 7 Aligned maps of selected RecQ-family helicases showing the relative lengths of the proteins, and the locations of the conserved helicase domains. Sequences include the amino acid sequence deduced from the M. anisopliae TAH1 ORF present in the clone pMAT3A1. Adapted from Bjergbaek et al. (2002)

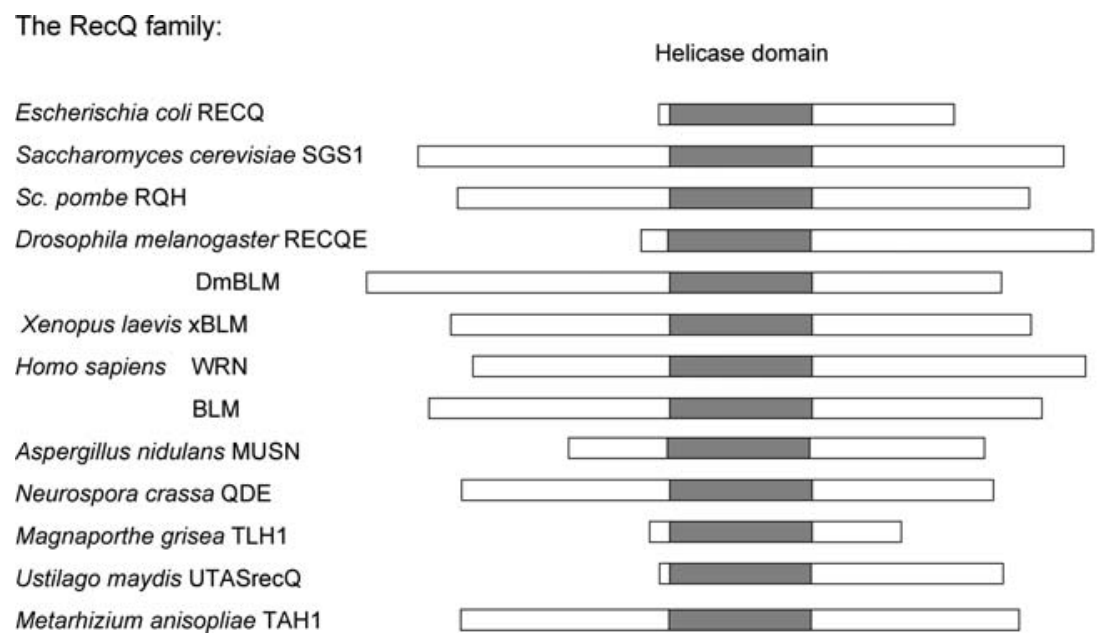

610AA 1447AA 1328AA 1058AA 1487AA 1367AA 1432AA 1417AA 1050AA 1252AA 559AA 757AA 1270AA 


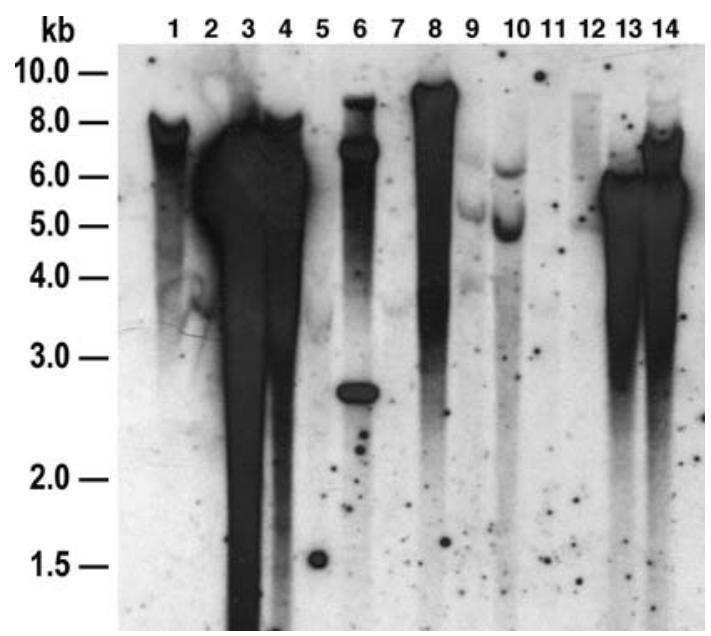

Fig. 8 Southern hybridization analysis of $M$. anisopliae strains (labelled 1-14 as in Table 1). Genomic DNA was digested with $E c o$ RI. The EcoRV-BamHI fragment of pMAT3A1, containing the bulk of the $M$. anisopliae $T A H 1$ gene, was used as the probe

single intense telomeric band, suggesting that in these cases all chromosomes were affected by either an amplification event targeted to the telomere or subtelomere, or by extensive recombination resulting in the homogenization of the chromosome ends. This lack of TAS polymorphism, at least within the DNA size range that is resolved by standard agarose gel electrophoresis, appears to be a common phenomenon in these strains of filamentous fungi. In the cases of $P$. fumosoroseus and $M$. anisopliae, we could not correlate the presence of monomorphic TASs with the host of origin or the geographic source of the fungal isolates examined. All the Gliocladium sp. isolates used in this study originated from Brazilian soils and were originally selected on the basis of their ability to suppress other moulds. Moreover, possession of a monomorphic TAS did not correlate with groups recognized on the basis of RAPD PCR typing (data not shown). Furthermore, the telomeric fingerprints of the remainder of the Gliocladium isolates with polymorphic TAS showed the group to have generally low genetic similarity. This suggests that the acquisition of monomorphic TAS in these filamentous fungi is a random event that has occurred independently in different isolates.

Although $M$. anisopliae strain CG34 possesses a monomorphic TAS, the $[\mathrm{TTAGGG}]_{n}$ telomere repeat arrays appear normal. The telomere lengths in CG34 are of a similar order to those seen in A. nidulans $(\sim 100 \mathrm{bp}$; Bhattacharyya and Blackburn 1997) and in the VR telomere of $N$. crassa (162 bp; Schectman 1990). The variation observed in telomere length in the partially sequenced $M$. anisopliae TAS clones is unlikely to be an artifact of enzymatic processing with the proofreading DNA polymerase used since, in the presence of excess dNTPs, loss of telomeric DNA should be minimal (Zakian 1989). Furthermore, telomere-repeat arrays are known to show heterogeneity in length even when derived from a particular chromosome (Zakian 1989). Little systematic information is available on telomere length in filamentous fungi, since telomeres are usually poorly represented in the libraries used for genome sequencing projects. For example, no clones hybridizing to a Neurospora telomeric sequence (Schectman 1990) were found in a $N$. crassa cosmid library of 12,000 clones (at least nine genome equivalents; Kelkar et al. 2001).

Among the filamentous fungi, genes for RecQ-like helicases have been found in the subtelomeric DNAs of U. maydis (UTASrecQ; Sánchez-Alonso and Guzmán 1998) and Magnaporthe grisea (TLH1, Gao et al. 2002). In the $U$. maydis strain FB2 a2b2, the helicase gene was found on a clone containing the subtelomeric repeat, UTASa. This repeat hybridized to 15 chromosomes in electrophoretic karyotypes of the source strain, but hybridized to only two chromosomes in a second strain, I2. The number of individual chromosome ends possessing a copy of $U T A \operatorname{Srec} Q$ has not been reported. In two isolates of $M$. grisea from rice, a RecQ-like helicase gene (designated TLH1,) which resembles UTASrec $Q$ from U. maydis, was found within $15 \mathrm{~kb}$ of at least seven and four of the 14 chromosome ends, respectively (Gao et al. 2002). TLH1 was detected by hybridization, with a copy number between two and five, in more than $100 \mathrm{M}$. grisea strains isolated from rice and collected in Korea in 1999. This prevalence was
Fig. 9 Presumed mechanism of chromosome end homogenization. A single TAS (with an embedded helicase gene) is used as a template for recombination-dependent transfer of TAS to other chromosome ends, resulting in the reduction or elimination of subtelomeric restriction fragment polymorphism. The letters above the bars indicate arbitrary unique restriction sites and the circles represent telomere repeats

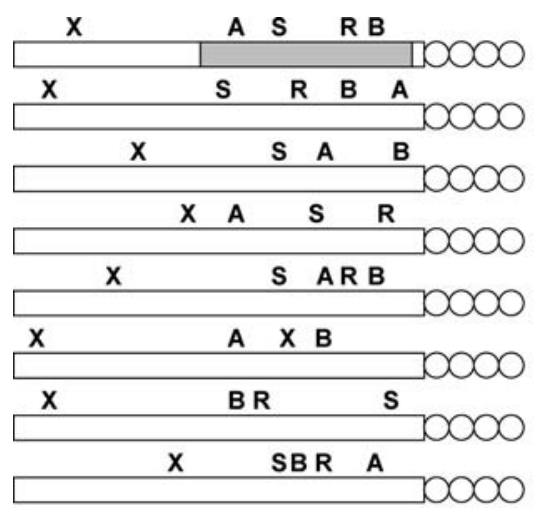

Polymorphic

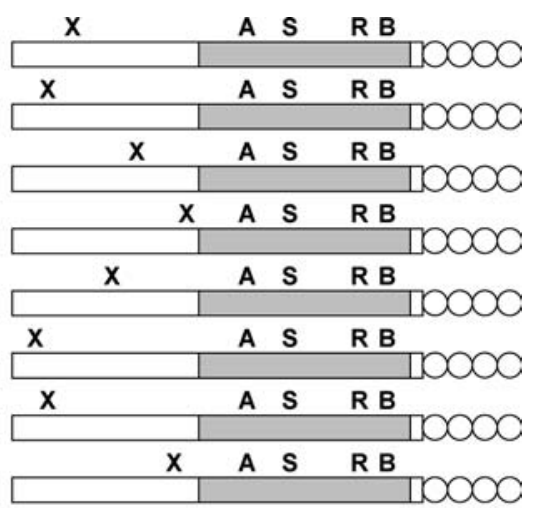

Monomorphic 
compatible with the fact that the strains exhibited over $90 \%$ identity in RFLPs detectable with a repetitive DNA probe (Gao et al. 2002). However, the TLH1 gene family could not be detected by hybridization in most isolates recovered from host plants other than rice. In contrast, cross-hybridization with the $T A H 1$ probe from CG34 reveals that the gene shows no correlation with host origin, as homologous sequences are found in $M$. anisopliae strains collected from both the insect orders Homoptera and Coleoptera, as well as from different families within the Coleoptera.

At least in $M$. anisopliae, the appearance of anomalous or monomorphic TAS was strongly associated with the possession of a TAH1 homologue. The strength of the hybridization signals obtained was highly variable, indicating significant sequence divergence in this gene between isolates. This variability may even apply to multiple copies of the gene in the same isolate. In $U$. maydis, the sequence of the helicase gene from a second clone of UTASa from strain FB2 a $2 b 2$ differed from the first by $10 \%$ (Sanchez-Alonso and Guzman 1998). The strong divergences in RecQ-like helicase sequences found in these fungi probably account for the lack of significant hybridization signals with DNA from Gliocladium spp. and $P$. fumosoroseus. Interestingly, it seems that telomere-associated $T A H 1$ homologues in the polymorphic $M$. anisopliae strains CG490 and CG491 are closely related to the gene from CG34, despite the different geographical and host origins of these strains.

The role of the RecQ helicases in the amplification and homogenization of subtelomeric DNA of $M$. anisopliae, U. maydis and M. grisea is currently unclear, although it may be related in some way to the maintenance of genome stability. One of the best-understood RecQ-type helicases is SGS1 from S. cerevisiae, which is required for faithful chromosome segregation (Watt et al. 1995, 1996). Yeast $\operatorname{sgs}_{1}$ mutants are also subject to premature senescence (Sinclair et al. 1997). Deleterious mutations in the human RecQ-genes involved in Bloom's disease (BLM; Ellis et al. 1995) and Werner's disease ( $W R N$; $\mathrm{Yu}$ et al. 1996) give rise to premature ageing phenotypes and a predisposition to cancer, which are reflected in genetic instability at the cellular level.

Telomere-targeted interchromosomal duplication of an element encoding a RecQ-like helicase in M. anisopliae strain CG34 has strong parallels with the $\mathrm{Y}^{\prime}$ elements of yeast, which are present in single or multiple tandem copies in subtelomeric DNA (Louis and Haber 1992). In the sequenced strain of $S$. cerevisiae, S288C, $\mathrm{Y}^{\prime}$ elements are found at 17 out of 32 telomeres (Louis 1995). In comparison, our restriction mapping data suggest that the TAHI-containing TAS in M. anisopliae strain CG34 is likely to be present at 12 of the 14 chromosome ends. The yeast $\mathrm{Y}^{\prime}$ element possesses an ORF for a product that shows $27 \%$ identity to helicases (although not closely related to RecQ helicases), and exists in two forms, long and short, which differ by several insertions or deletions within this region (Louis and Haber 1992). Y' elements are highly conserved, showing only $0.3-1.13 \%$ sequence divergence within a strain and $1.15-1.75 \%$ divergence between strains, contrasting with $8-18 \%$ divergence among adjacent subtelomeric repeats. Yeast cells in which telomerase has been inactivated are known to senesce due to gradual erosion of telomeres. A small proportion of the senescent cells are, however, able to survive and multiply by activation of a telomerase-independent mechanism of telomere maintenance (Lundblad and Blackburn 1993). These survivors can be divided into two types: type I survivors have high levels of amplification of $\mathrm{Y}^{\prime}$ elements in tandem arrays, whereas type II survivors have very long tracts of $\left[\mathrm{TG}_{1-3}\right]$ telomere repeats. Although the structure and distribution of $\mathrm{Y}^{\prime}$ suggests an origin as a mobile element, activation and the development of both types of telomerase-deficient survivors is dependent on recombination and requires $R A D 52$ (Lundblad and Blackburn 1993) and either RAD50 or RAD51 (Teng and Zakian 1999). Furthermore, production of type II survivors has been shown to be dependent on SGSI (Cohen and Sinclair 2001; Huang et al. 2001).

We were not able to detect a TAHI transcript by northern blotting of RNA from $M$. anisopliae strain CG34, grown under normal conditions. Likewise, northern analysis failed to detect transcripts from an $M$. grisea strain that has an amplified subtelomeric TLH1 gene, when grown under a range of conditions including carbon and nitrogen-source starvation, heat and cold shocks and exposure to mutagenic agents. Similarly, no transcripts could be detected in the progeny of a cross between the strain possessing the amplified TLH1 gene and a second laboratory strain (Gao et al. 2002). However, Yamada et al. (1998) showed that the helicase gene on the yeast $\mathrm{Y}^{\prime}$ element is expressed in telomerase-deficient yeast survivors, producing a protein, $Y^{\prime}$-Help1, with helicase activity. However, the exact role of this protein in the $\mathrm{Y}^{\prime}$ amplification process is as yet unclear. The lack of a detectable TAHI transcript in $M$. anisopliae could indicate that the TAS is now stable in the strain analysed and that the gene plays no role in normal cellular housekeeping. Moreover, the gene may also be subject to telomeric silencing (Gottschling et al. 1990).

Phylogenetic analysis of selected RecQ-like helicase cores showed that the subtelomeric helicases of filamentous fungi form a separate clade, distinct from other helicases. This topology probably reflects a significant difference between these two classes of helicase, possibly related to the presumed mobile nature of the subtelomeric helicase genes. The position of the helicase core relative to the whole protein appears to be highly variable among the helicases included in our analysis. The helicases with core domains positioned towards the N-terminal end tend to be smaller proteins, suggesting either redundancy of function of the $\mathrm{N}$-terminal portions of those proteins that possess them or that these regions are important for specific functions. It is known, for example, that the first 106 amino acids of the 1,447-residue $S$. cerevisiae SGS1 
protein are essential for binding to DNA topoisomerase III and that their coordinated interaction is important for their function in the processing of DNA after exposure of cells to DNA-damaging agents (Bennett and Wang 2001; Hu et al. 2001). This difference between $M$. anisopliae TAHI and the other telomere-associated helicase genes from $U$. maydis and $M$. grisea could be associated with the variation in the distribution of the apparent insertions: the Metarhizium TAS is present at almost all telomeres and displays little RFLP. The shorter helicases encoded by the TASs of $U$. maydis and $M$. grisea could derive from inactive remnants of a similar element that have been homogenized by recombination.

The occurrence of ORFs for RecQ helicases in the subtelomeric DNA of the filamentous fungi $M$. anisopliae, U. maydis and M. grisea, and in the analogous $\mathrm{Y}^{\prime}$ element found in Saccharomyces yeasts, implies that this class of element could be an ancient addition to the fungal genome. However, while all laboratory strains of $S$. cerevisiae and closely related species possess a $\mathrm{Y}^{\prime}$ element (Louis 1995; Naumov et al. 2000), strains of the sibling species $S$. bayanus - and yeast strains outside this group of species-have no $\mathrm{Y}^{\prime}$ (Naumov et al. 1992; Pryde and Louis 1997). Furthermore, the discontinuous distribution of these subtelomeric elements among $M$. grisea and $U$. maydis isolates, and our data for Metarhizium, Gliocladium and Paecilomyces, suggest that this character is not intrinsic to these fungi. Instead, it appears that it is the capacity for amplification of TASs containing helicase genes that is evolutionarily conserved in fungi.

Acknowledgements PWI was the recipient of a visiting post-doctoral fellowship from the Brazilian National Research Council (Conselho Nacional de Desenvolvimento Cientifico e Tecnologico, $\mathrm{CNPq}$ ) and MCVI was a post-doctoral $\mathrm{CNPq}$ visiting fellow at the Department of Genetics, University of Leicester, UK during the period of this research. EJL is funded by The Wellcome Trust. The authors also thank EMBRAPA for additional financial support.

\section{References}

Altschul SF, Madden TL, Schäffer AA, Zhang J, Zhang Z, Miller W, Lipman DJ (1997) Gapped BLAST and PSI-BLAST: a new generation of protein database search programs. Nucleic Acids Res 25:3389-3402

Bennett RJ, Wang JC (2001) Association of yeast DNA topoisomerase III and Sgs1 DNA helicase: studies of fusion proteins. Proc Natl Acad Sci USA 98:11108-11113

Bhattacharyya A, Blackburn EH (1997) Aspergillus nidulans maintains short telomeres throughout development. Nucleic Acids Res 25:1426-1421

Bjergbaek L, Cobb JA, Gasser SM (2002) RecQ helicases and genome stability: lessons from model organisms and human disease. Swiss Med Wkly 132:433-442

Blackburn EH, Challoner PB (1984) Identification of a telomeric DNA sequence in Trypanosoma brucei. Cell 36:447-457

Boucias DG, Tigano MS, Sosa-Gomez DR, Glare TR, Inglis PW (2000) Genotypic and phenotypic properties of the invertebrate mycopathogen Nomuraea rileyi. Biol Control 19:124-138
Cohen H, Sinclair DA (2001) Recombination-mediated lengthening of terminal telomeric repeats requires the SGS1 DNA helicase. Proc Natl Acad Sci USA 98:3174-3179

Danilevskaya ON, Arkhipova IR, Traverse KL, Pardue ML (1997) Promoting in tandem: the promoter for telomere transposon $H e T-A$ and implications for the evolution of retroviral LTRs. Cell 88:647-655

De la Cruz J, Kresslerand D, Linder P (1999) Unwinding RNA in Saccharomyces cerevisiae: DEAD-box proteins and related families. Trends Biochem Sci 24:192-198

Ellis NA, Groden J, Ye T, Straughen J, Lennon DJ, Ciocci S, Proytcheva M, German J (1995) The Bloom's syndrome gene product is homologous to RecQ helicases. Cell 83:655-666

Fargues JF, Robert PH (1983) Effects of passage through scarabeid hosts on virulence and host specificity of two strains of the entomopathogenic hyphomycete Metarhizium anisopliae. Can J Microbiol 29:576-583

Forney J, Henderson ER, Blackburn EH (1987) Identification of the telomeric sequence of the acellular slime molds Didnium iridis and Physarum polycephalum. Nucleic Acids Res 15:91439152

Gao W, Khang CH, Park SY, Lee YH, Kang S (2002) Evolution and organization of a highly dynamic, subtelomeric helicase gene family in the rice blast fungus Magnaporthe grisea. Genetics 162:103-112

Gorbalenya AE, Koonion EV, Donchenko AP, Blinov VM (1989) Two related superfamilies of putative helicases involved in replication, recombination, repair and expression of DNA and RNA genomes. Nucleic Acids Res 17:4713-4729

Gottschling DE, Aparicio OM, Billington BL, Zakian VA (1990) Position effect at $S$. cerevisiae telomeres: reversible repression of PolII transcription. Cell 63:751-762

Guzmán PA, Sánchez JG (1994) Characterization of telomeric regions from Ustilago maydis. Microbiology 140:551-557

Henikoff S (1987) Unidirectional digestion with exonuclease III in DNA sequence analysis. Methods Enzymol 155:156-165

$\mathrm{Hu}$ P, Beresten SF, van Brabant AJ, Ye TZ, Pandolfi PP, Johnson FB, Guarente L, Ellis NA (2001) Evidence for BLM and Topoisomerase IIIalpha interaction in genomic stability. Hum Mol Genet 10:1287-1298

Huang P, Pryde FE, Lester D, Maddison RL, Borts RH, Hickson ID, Louis EJ (2001) SGS1 is required for telomere elongation in the absence of telomerase. Curr Biol 11:125-129

Inglis PW, Magalhães BP, Valadares-Inglis MC (1999) Genetic variability in Metarhizium flavoviride revealed by telomeric fingerprinting. FEMS Microbiol Lett 179:49-52

Inglis GD, Goettel MS, Butt TM, Strasse H (2001a) Use of hyphomycetous fungi for managing insect pests. In: Butt TM, Jackson CW, Magan N (eds) Fungi as biocontrol agents-progress, problems and potential. CABI Publishing, Wallingford, pp 23-48

Inglis PW, Teixeira EA, Ribeiro DM, Valadares-Inglis MC, Tigano MS, Mello SCM (2001b) Molecular markers for the characterization of Brazilian Cercospora caricis isolates. Curr Microbiol 42:194-198

Kelkar HS, Griffith J, Case ME, Covert SF, Hall RD, Keith CH, Oliver JS, Orbach MJ, Sachs MS, Wagner JR, Weise MJ, Wunderlich JK, Arnold J (2001) The Neurospora crassa genome: cosmid libraries sorted by chromosome. Genetics 157:979-990

Langewald J, Ouambama Z, Mamadou A, Peveling R, Stolz I, Bateman R, Attignon S Blanford S, Arthurs S, Lomer C (1999) Comparison of an organophosphate insecticide with a mycoinsecticide for the control of Oedaleus senegalensis Krauss (Orthoptera: Acrididae) and other Sahelian grasshoppers in the field at operational scale. Biocontrol Sci Technol 9:199-214

Levis RW, Ganesan R, Houtchens K, Tolar LA, Sheen FM (1993) Transposons in place of telomeric repeats at a Drosophila telomere. Cell 75:1083-1093

Levis C, Giraud T, Dutertre M, Fortini D, Brygoo Y (1997) Telomeric DNA of Botrytis cinerea: a useful tool for strain identification. FEMS Microbiol Lett 157:267-272 
Louis EJ (1995) The chromosome ends of Saccharomyces cerevisiae. Yeast 11:1553-1573

Louis EJ, Haber JE (1992) The structure and evolution of subtelomeric $\mathrm{Y}^{\prime}$ repeats in Saccharomyces cerevisiae. Genetics 131:559-574

Lundblad V, EH Blackburn (1993) An alternative pathway for yeast telomere maintenance rescues est 1 -senescence. Cell 73:347-360

Magalhães BP (1997) Microbial control of grasshoppers in Brazil with the use of entomopathogenic fungi. In: Martins MT, Satto MIZ, Tiedje JM, Hagler LCN, Dobereiner J (eds) Progress in microbial ecology. Brazilian Society for Microbiology/ICOME, Santos, pp 429-433

McHale MT, Roberts IN, Noble SM, Beaumont C, Whitehead MP, Seth D, Oliver RP (1992) CfT-I: an LTR retrotransposon in Cladosporium fulvum, a fungal pathogen of tomato. Mol Gen Genet 233:337-347

Meyne J, Ratliff RL, Moyzis RK (1989) Conservation of the human telomere sequence (TTAGGG) ${ }_{n}$ among vertebrates. Proc Natl Acad Sci USA 86:7049-7053

Moore D, Bridge PD, Higgins PM, Bateman RP, Prior C (1993) Ultra-violet radiation damage to Metarhizium flavoviride conidia and the protection given by vegetable and mineral oils and chemical sunscreens. Ann Appl Biol 122:605-616

Naumov GI, Naumova ES, Lantto RA, Louis EJ, Korhola M (1992) Genetic homology between Saccharomyces cerevisiae and its sibling species $S$. paradoxus and S. bayanus: electrophoretic karyotypes. Yeast 8:599-612

Naumov GI, James SA, Naumova ES, Louis EJ, Roberts IN (2000) Three new species in the Saccharomyces sensu stricto complex: Saccharomyces cariocanus, Saccharomyces kudriavzevii and Saccharomyces mikatae. Int J Syst Evol Microbiol 50:19311942

Okazaki S, Ishikawa H, Fujiwara H (1995) Structural analysis of $T R A S 1$, a novel family of telomeric repeat-associated retrotransposons in the silkworm, Bombyx mori. Mol Cell Biol 15:4545-4552

Pearson WR, Lipman DJ (1988) Improved tools for biological sequence comparison. Proc Natl Acad Sci USA 85:2444-2448

Poulter RTM, Goodwin TJD, Butler MI (2003) Vertebrate helentrons and other novel Helitrons. Gene 313:201-212

Powell WA, Kistler HC (1990) In vivo rearrangement of foreign DNA by Fusarium oxysporum produces linear self-replicating plasmids. J Bacteriol 172:3163-3171

Prior C (1992) Discovery and characteristics of fungal pathogens for locust and grasshopper control. In: Lomer CJ, Prior C (eds) Biocontrol of locusts and grasshoppers. CABI International, Wallingford, pp159-180

Pryde FE, Louis EJ (1997) Saccharomyces cerevisiae telomeres. Biochemistry (Moscow) 62:1232-1241

Ryan MJ, Bridge PD, Smith D, Jeffries P (2002) Phenotypic degeneration occurs during sector formation in Metarhizium anisopliae. J Appl Microbiol 93:163-168

Saitou N, Nei M (1987) The neighbor-joining method: a new method for reconstructing phylogenetic trees. Mol Biol Evol $4: 406-425$
Sanchez-Alonso P, Guzman PA (1998) Organization of chromosome ends in Ustilago maydis RecQ-like helicase motifs at telomeric regions. Genetics 148:1043-1054

Sanchez-Alonso P, Valverde ME, Paredes-Lopez O, Guzman P (1996) Detection of genetic variation in Ustilago maydis strains by probes derived from telomeric sequences. Microbiology 142:2931-2936

Schechtman MG (1990) Characterization of telomere DNA from Neurospora crassa. Gene 88:159-165

Shimizu S, Arai Y, Matsumoto T (1992) Electrophoretic karyotype of Metarhizium anisopliae. J Invertebr Pathol 60:185-187

Sinclair DA, Mills K, Guarente L (1997) Accelerated ageing and nuceolar fragmentation in yeast sgsl mutants. Science 277:1313-1316

Takahashi H, Okazaki S, Fujiwara H (1997) A new family of sitespecific retrotransposons, $S A R T 1$, is inserted into telomeric repeats of the silkworm, Bombyx mori. Nucleic Acids Res 25:1578-1584

Teng SC, Zakian VA (1999) Telomere-telomere recombination is an efficient pathway for telomere maintenance in Saccharomyces cerevisiae. Mol Cell Biol 19:8083-8093

Valadares-Inglis MC, Peberdy JF (1998) Variation in the electrophoretic karyotype of Brazilian strains of Metarhizium anisopliae. Genet Mol Biol 21:11-14

Viaud M, Couteaudier Y, Riba G (1998) Molecular analysis of hypervirulent somatic hybrids of the entomopathogenic fungi Beauveria bassiana and Beauveria sulfurescens. Appl Environ Microbiol 64:88-93

Watt PM, Louis EJ, Borts RH, Hickson ID (1995) SGS1: a eukaryotic homologue of $E$. coli $\operatorname{rec} Q$ that interacts with topoisomerase II in vivo and is required for faithful chromosome segregation. Cell 81:253-260

Watt PM, Hickson ID, Borts RH, Louis EJ (1996) SGS1, a homologue of the Bloom's and Werner's syndrome genes, is required for maintenance of genome stability in Saccharomyces cerevisiae. Genetics 144:935-945

Weiss-Schneeweiss H, Riha K, Jang CG, Puizina J, Scherthan H, Schweizer D (2004) Chromosome termini of the monocot plant Othocallis siberica are maintained by telomerase, which specifically synthesises vertebrate-type telomere sequences. Plant J 37:484-493

Wraight SP, Jackson MA, Kock SL (2001) Production, stabilization and formulation of fungal biocontrol agents. In: Butt TM, Jackson CW, Magan N (eds) Fungi as biocontrol agents-progress, problems and potential. CABI Publishing, Wallingford, pp 253-287

Yamada M, Hayatsu N, Matsuura A, Ishikawa F (1998) Y'-Help1, a DNA helicase encoded by the yeast subtelomeric $\mathrm{Y}^{\prime}$ element, is induced in survivors defective for telomerase. J Biol Chem 273:33360-33366

Yu CE, Oshima J, Fu YH, Wijsman EM, Hisama F, Alisch R, Matthews S, Nakura J, Miki T, Ouais S, Martin GM, Mulligan J, Schellenberg GD (1996) Positional cloning of the Werner's syndrome gene. Science 272:258-262

Zakian VA (1989) Structure and function of telomeres. Annu Rev Genet 23:579-604 